\title{
SEVEN TAXONOMIC DISCOVERIES IN ANNONACEAE FROM SOUTH-EASTERN CENTRAL AMERICA
}

\author{
ROY H.J. ERKENS ${ }^{1,5}$, PAUL J.M. MAAS ${ }^{1}$, LARS W. CHATROU ${ }^{2}$, \\ GEORGE E. SCHATZ ${ }^{3} \&$ NELSON ZAMORA ${ }^{4}$
}

\begin{abstract}
SUMMARY
During fieldwork in Costa Rica and Panama five undescribed species of Guatteria and one new species of Desmopsis were collected and are described here. Additionally, a poorly known species of Pseudomalmea is described.
\end{abstract}

Key words: Annonaceae, Desmopsis, Guatteria, Pseudomalmea, Costa Rica, Panama, endemics.

\section{INTRODUCTION}

Guatteria (Annonaceae) is a large genus of neotropical trees, comprising c. 265 species (Chatrou et al., 2004). Ruiz \& Pavón described the genus as early as 1794, but the last and only revision dates back to Fries (1939). The genus itself is easily recognised by its impressed primary vein on the upper side of the leaf, valvate sepals, almost always imbricate petals, numerous carpels (with a single basal ovule), and a pedicel with a distinct suprabasal articulation. The species of Guatteria, however, are very homogeneous in many morphological characters, such as habit, flower shape, and number of monocarps. This makes it difficult to understand the systematics and evolution of the genus. Phylogenetic analyses (Erkens et al., in prep.) based on four plastid markers show that Guatteria is monophyletic and that most of the endemic Central American Guatteria species form a monophyletic group. In order to understand the evolutionary history of these Central American species better, fieldwork in Costa Rica and Panama was carried out by Paul Maas, Hiltje Maas-van de Kamer, and Roy Erkens of the National Herbarium of the Netherlands, Utrecht University branch, and Nelson Zamora, curator of the herbarium of the Instituto Nacional de Biodiversidad (INBio), Santa Domingo de Heredia, Costa Rica, during the months of May and June 2004. With regard to Guatteria, Costa Rica has been well collected but in Panama there are many undercollected areas. Material of many Guatteria species was collected during this trip, including five unnamed species, which are described here.

1) Nationaal Herbarium Nederland, Utrecht University branch, W.C. van Unnikgebouw, Heidelberglaan 2, 3584 CS Utrecht, The Netherlands.

2) Nationaal Herbarium Nederland, Wageningen University branch, Generaal Foulkesweg 37, 6703 BL Wageningen, The Netherlands.

3) Missouri Botanical Garden, P.O. Box 299, St Louis, Missouri 63166-0299, U.S.A.

4) Instituto Nacional de Biodiversidad, P.O. Box 22-3100, Santo Domingo de Heredia, Costa Rica.

5) Author for correspondence (R.H.J.Erkens@ bio.uu.nl). 


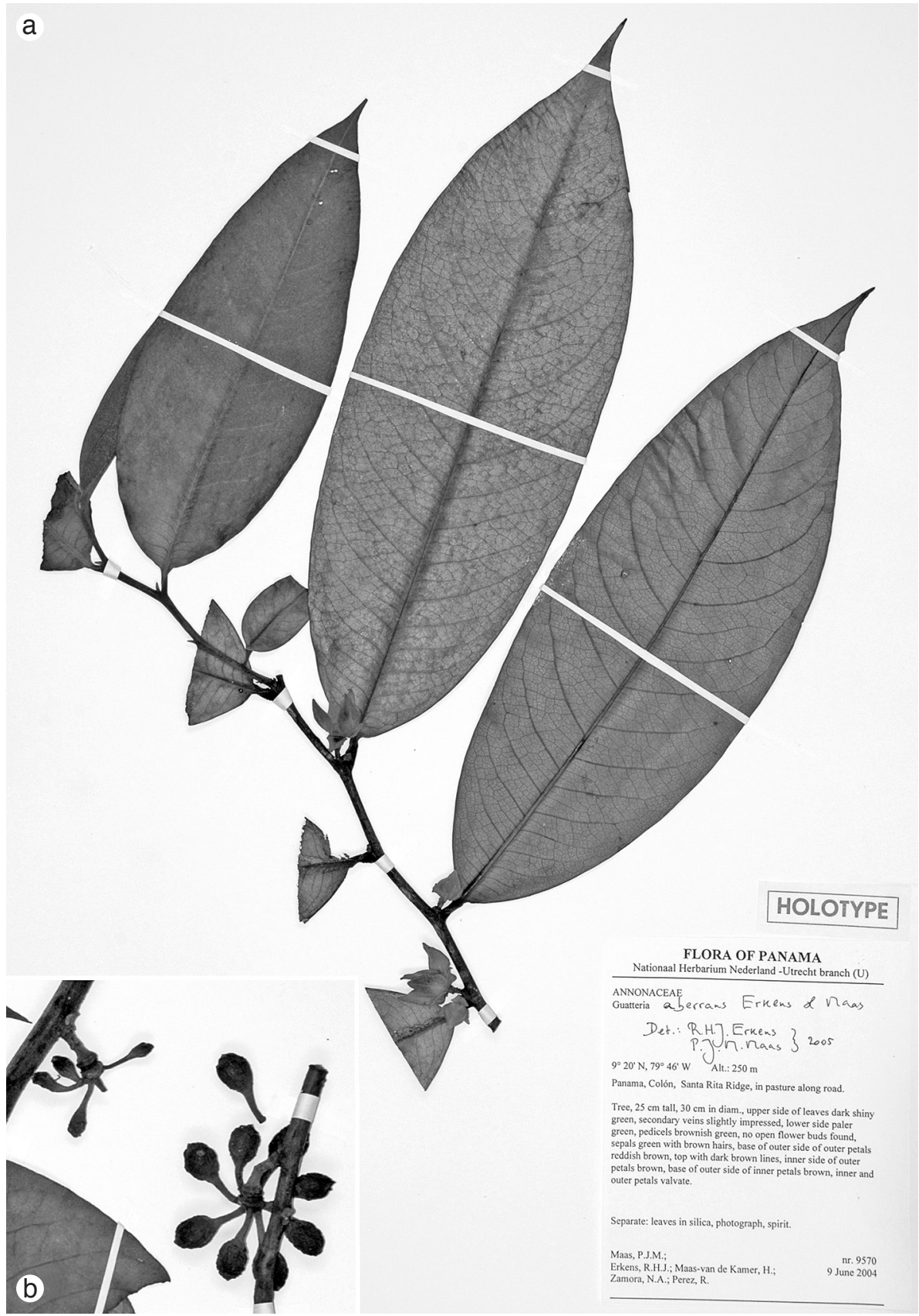

Fig. 1. Guatteria aberrans Erkens \& Maas. a. Flowering twig; b. (inset) fruiting twig (a: Maas et al. 9570; b: Maas et al. 9564). 
Additionally, a new species of Desmopsis and a new species in Pseudomalmea are described. The new species of Desmopsis was collected by Lars Chatrou et al. on a previous collecting trip to Costa Rica. Its name, $D$. verrucipes, was recognised already by Zamora et al. (2000) and is validated here.

\section{MATERIALS AND METHODS}

Herbarium material was investigated from the following herbaria: CR, DUKE, F, GH, INB, K, MO, NY, PMA, SCZ, TEX, U, USJ, and WIS. Measurements as a rule were made on dried material. Measurements on material in spirit are given between accolades \{\} . Colour indications and descriptions of surface structures are based on dried material, unless stated otherwise. We indicate the density of the indument by using the following gradations: densely, rather densely, and sparsely.

\section{DESCRIPTION OF SPECIES}

\section{GUATTERIA}

\section{Guatteria aberrans Erkens \& Maas, spec. nov. - Fig. 1; Plate 1; Map 1}

Guatteria alabastris acutis G. pannosae proxima, sed foliis anguste ellipticis vel anguste ovatis nec anguste oblongis vel raro ellipticis et indumento densiore distincta. - Typus: Maas, Erkens, Maas-van de Kamer, Zamora \& Pérez, 9570 (holo U; iso INB, K, MO, PMA, SCZ), Panama, Colón, Santa Rita Ridge, Parcela 31 of CTFS, 250 m, 9 June 2004.

Tree 8-25 m tall, trunk 10-30 cm diam.; young twigs densely covered with erect, curly, brown hairs, soon glabrous. Leaves: petiole 5-10 mm long, 2-3 mm diam., decurrent as prominent ridge in young twigs; lamina narrowly elliptic to sometimes narrowly ovate, $15-32$ by $4-9.5 \mathrm{~cm}$ (leaf index $2.9-3.7$ ), coriaceous, not verrucose, shiny above in vivo, dark blackish brown to grey above, brown to pale brown below, sparsely covered with appressed hairs above, soon glabrous, sparsely covered with appressed hairs below, base obtuse, sometimes slightly attenuate, apex acuminate (acumen 10-15 mm long), secondary veins distinct, 15-18 on either side of primary vein, prominent above, angles with primary vein $45-60^{\circ}$, loop-forming at almost right angles, smallest distance between loops and margin 3-4 mm. Flowers solitary or in pairs; pedicels 7-10 $\mathrm{mm}$ long, 1-2 mm diam., fruiting pedicels 9-12 $\mathrm{mm}$ long, 2-3 mm diam., densely covered with erect, curly, brown hairs; flower buds ovoid, distinctly apiculate; sepals free, triangular to very broadly triangular, 7-10 by $5-8 \mathrm{~mm}$, patent but soon becoming completely reflexed, outer side densely covered with erect, curly, brown hairs; petals brown to chocolate-coloured in vivo, unequal, outer ones narrowly elliptic, basal margins reflexed outwards, $13-20\{-32\}$ by $5-7\{-9\} \mathrm{mm}$, inner ones valvate, narrowly triangular-ovate, base thickened and almost spur-like, bifacial (as in the genus Anaxagorea) above the middle, $15-20\{-32\}$ by $7-8\{-13\} \mathrm{mm}$, outer side densely covered with erect, curly, brown hairs; stamens c. $1.5 \mathrm{~mm}$ long, connective shield glabrous. Monocarps 10-40, young monocarps green in vivo, blackish in sicco, ellipsoid, 10-14 by 7-9 mm, sparsely covered with erect, curly, brown hairs, soon glabrous, apex minutely apiculate (apicle $<0.5 \mathrm{~mm}$ long), wrinkled in sicco, stipes 
9-14 by 1-2 mm, densely covered with erect, curly, brown hairs. Seeds ellipsoid, $10-12$ by $5-6 \mathrm{~mm}$, smooth.

Distribution - Panama (Comarca de San Blas, Colón).

Habitat \& Ecology - Forest, sometimes along roadsides. At elevations from sea level up to $250 \mathrm{~m}$.

Phenology - Flowering: February, June, July; fruiting: February, June.

Notes - Guatteria aberrans is strongly deviating from other species of Guatteria, except G. pannosa Scharf \& Maas, by its pointed flower buds and its valvate, almost spurred inner petals. Another peculiarity of this species is that the inner petals seem to stay closed during the whole life cycle (no open bud development seen). Cogollo \& Brand 373 (MO) from Colombia, Antioquia, Mun. San Luis, Highway Medellín - Bogotá, 2 km from Río Claro, near Río Samaná, alt. 790 m, probably belongs to this species. It matches G. aberrans in almost all aspects (pointed flower buds, leaf size, and flower size). Its flowers are annotated as pink ('rosada') and its fruits as black.

Guatteria pannosa, recently described from French Guiana and adjacent Brazil (Amapá; Scharf et al., 2005), shows a striking similarity in flower architecture. On the basis of other characters, however, it is fairly easy to distinguish both species (Table 1), and therefore G. aberrans is described as new. Its relationship to other species of Guatteria is unknown so far.

Etymology - This species is so named because of its aberrant flower type in comparison to the majority of Guatteria flowers or flower buds.

Paratypes:

Panama. Colón: Aizprúa \& Araúz 3375 (SCZ, U), Santa Rita Ridge, road to Agua Clara, 190 m; Aranda 3022 (SCZ, U), Santa Rita; Galdames et al. 4473 (SCZ, U), road to Sierra Llorona; Luque et al. 509 (PMA, U), Santa Rita; Luque et al. 566 (PMA, U), La Llana, Parque Nacionál Chagres; Maas, Erkens, Maas-van de Kamer, Zamora \& Pérez 9564 (INB, PMA, SCZ, U), Santa Rita Ridge, 200 m. Comarca de San Blas: de Nevers \& Herrera 7168 (MO, U), Cangandi, 30 m.

Table 1. Morphological differences between Guatteria aberrans Erkens \& Maas (Panama) and G. pannosa Scharf \& Maas (French Guiana, Brazil).

\begin{tabular}{lll}
\hline & G. aberrans & G. pannosa \\
\hline Petiole & $\begin{array}{c}\text { decurrent into the young twigs as a } \\
\text { protruding edge }\end{array}$ & not decurrent \\
Leaf base & obtuse & acute \\
Lamina & narrowly elliptic or sometimes nar- & narrowly oblong, rarely narrowly \\
& rowly ovate; $15-32$ by $4-9.5 \mathrm{~cm}$ & elliptic; $10-20$ by $2.5-4 \mathrm{~cm}$ \\
Lower side leaf & sparsely covered with appressed & densely covered with appressed \\
& hairs & hairs \\
Stipe length & $9-14 \mathrm{~mm}$ & $20-25 \mathrm{~mm}$ \\
\hline
\end{tabular}

2. Guatteria acrantha Erkens \& Maas, spec. nov. - Fig. 2, 3; Map 1

Guatteria floribus terminalibus pro ratione parvis, foliis parvis apice rotundatis distincta. - Typus: Rivera 355 (holo SCZ; iso PMA, U), Panama, Los Santos, Distr. Tonosí, Cerro Los Piraguales, El Cortezo, 900 m, 20 April 1994. 
Tree or shrub 5-20 m tall; young twigs sparsely covered with appressed hairs, soon glabrous. Leaves: petiole 1-3 mm long, $1 \mathrm{~mm}$ diam.; lamina narrowly obovate to narrowly elliptic, $5-8$ by $2-3.5 \mathrm{~cm}$ (leaf index $2.2-2.8$ ), chartaceous, not verrucose, dull dark brown above, brown to brownish green below, glabrous above, rather densely covered with appressed hairs below, base attenuate, apex rounded or sometimes very shortly and bluntly acuminate, secondary veins distinct, 6-9 on either side of primary vein, flat to slightly raised above, angles with primary vein $60-70^{\circ}$, loop-forming at right to obtuse angles, smallest distance between loops and margin 1-2 mm. Flowers solitary, terminal; pedicels 6-12 mm long, c. $1 \mathrm{~mm}$ diam., densely covered with appressed, brown hairs; flower buds broadly ovoid-deltoid; sepals free, ovate-triangular to deltate, $3-5$ by $3-4 \mathrm{~mm}$, appressed to reflexed, outer side densely covered with appressed, brown hairs; petals greenish in vivo, subequal, obovate, 7-9 by $5-7 \mathrm{~mm}$, outer side densely covered with appressed, brown hairs; stamens 1-1.5 mm long, connective shield papillate. Monocarps c. 10, green in vivo, black in sicco, narrowly ellipsoid, 7-10 by 3-4 mm, subglabrous, apex apiculate (apicle c. $1 \mathrm{~mm}$ long), stipes black, 1-2 by $1 \mathrm{~mm}$, subglabrous. Seeds narrowly ellipsoid, c. 8 by $3 \mathrm{~mm}$, pale brown, pitted.

Distribution - Panama (Veraguas, Los Santos).

Habitat \& Ecology - Cloud forest. At elevations of 900-1500 m.

Phenonoly - Flowering: February to April; fruiting: April.

Note - Guatteria acrantha is very well characterised by having terminal flowers, in combination with very small flowers for the genus (only 15-20 mm diam., petals $<10 \mathrm{~mm}$ long) and small leaves with a mostly rounded apex. Superficially, it looks similar to G. rotundata Maas \& Setten by the shape of its leaves, but it is quite distinct

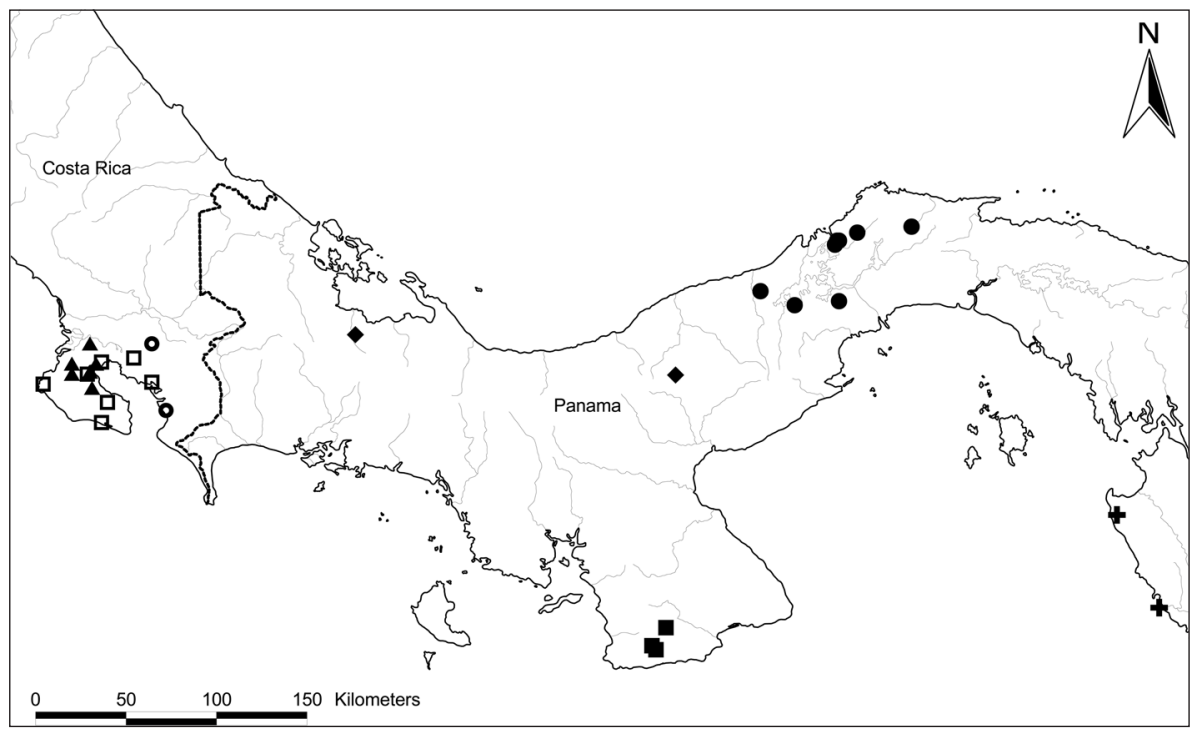

Map 1. Distribution of Guatteria aberrans Erkens \& Maas (-), G. acrantha Erkens \& Maas (ם), G. reinaldii Erkens \& Maas (O), G. rostrata Erkens \& Maas ( $\mathbf{\Delta})$, G. zamorae Erkens \& Maas $(\bullet)$, Desmopsis verrucipes Chatrou, G.E. Schatz \& N. Zamora (ㅁ), and Pseudomalmea darienensis Chatrou (\$) in Costa Rica and Panama. 


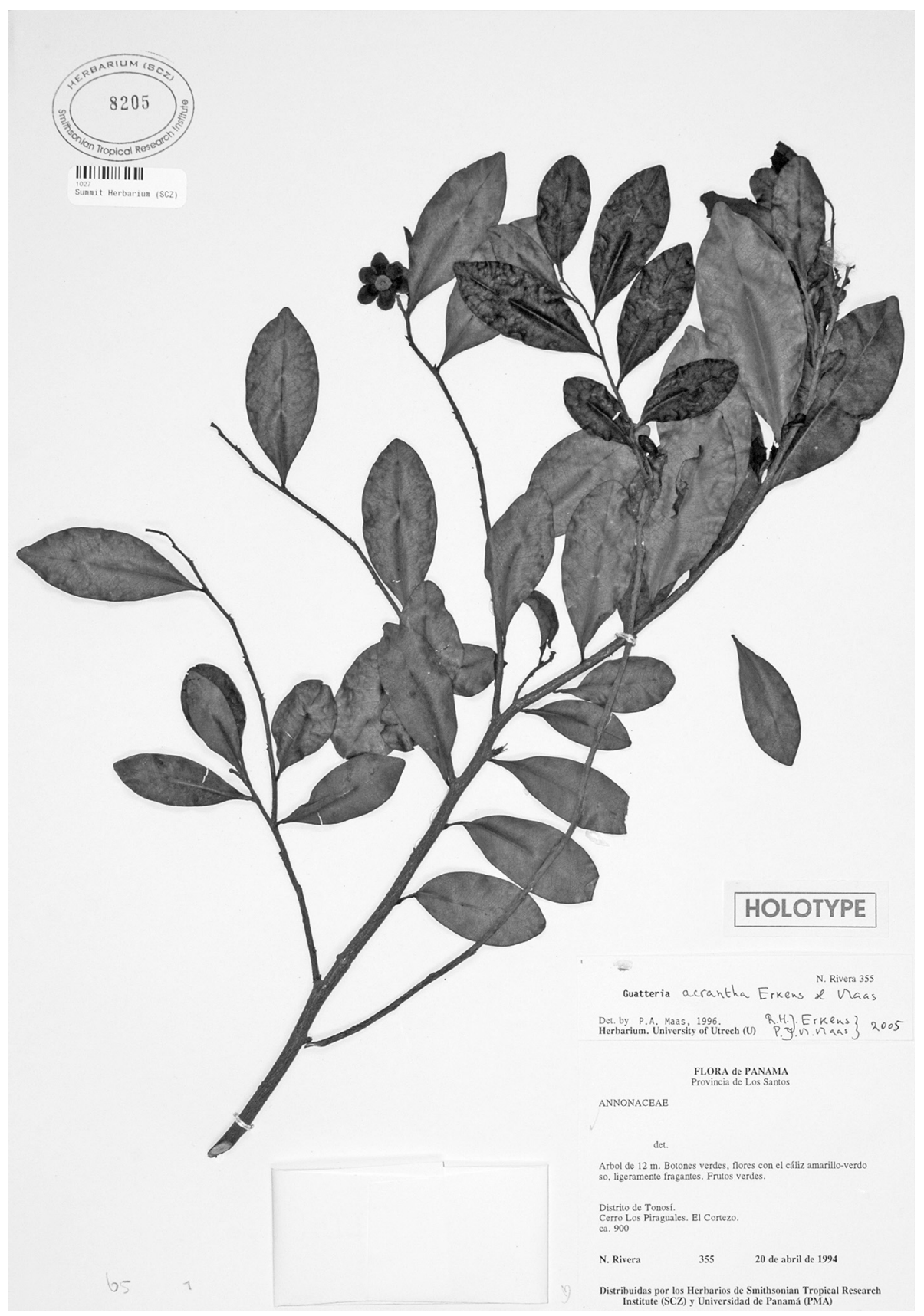

Fig. 2. Guatteria acrantha Erkens \& Maas. Flowering branch (Rivera 355). 


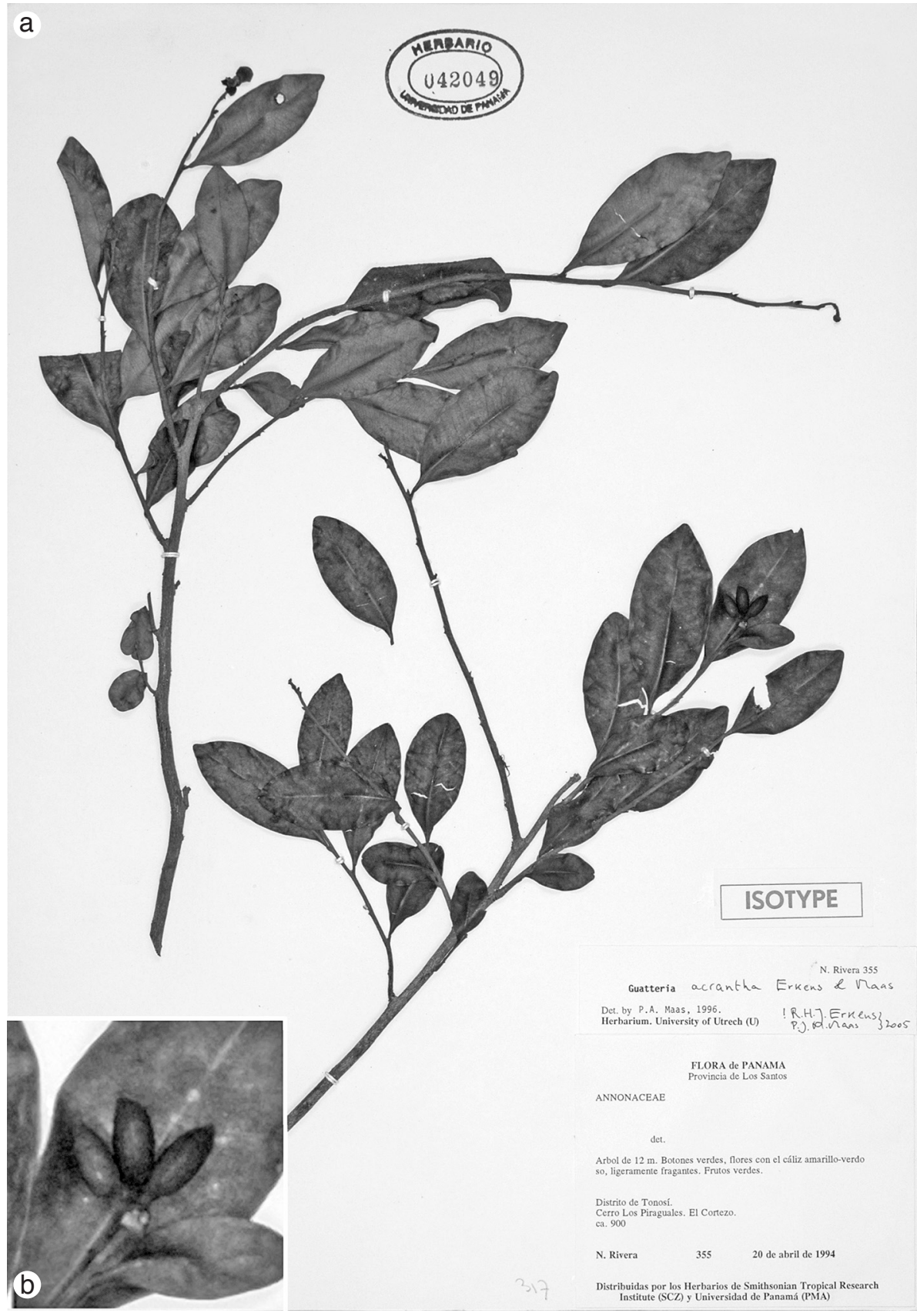

Fig. 3. Guatteria acrantha Erkens \& Maas. a. Flowering and fruiting twig; b. close-up of fruit (all: Rivera 355). 
by having terminal flowers. The only other Central American species of Guatteria with terminal flowers is G. grandiflora Donn.Sm. (incl. G. anomala R.E. Fr.), a species occurring in Mexico, Guatemala, and Honduras, but the latter species has much larger flowers (petals $22-42 \mathrm{~mm}$ long) and leaves $(5.5-22$ by $2-7 \mathrm{~cm})$.

Etymology - From 'akros' (top) and 'anthos' (flower), referring to the terminal flower, the distinguishing feature of this new species.

Paratypes:

Panama. Veraguas: Deago et al. 265 (PMA, SCZ), Distr. Montijo, Cerro Hoya, ascending to Cobachón; Deago et al. 371 (U), Distr. Montijo, Cerro Hoya, ascending to Río Pedregal, 1500 m.

\section{Guatteria reinaldii Erkens \& Maas, spec. nov. - Fig. 4; Map 1}

Guatteriae pudicae proxima, sed foliis leviter falcatis, venis secundariis paucioribus differt. - Typus: Aguilar et al. 2031 (holo INB; iso U), Costa Rica, Puntarenas, Cantón de Osa, Fila Costena, 2 km N of Piedras Blancas, near Cerro Anguciana, 900 m, 28 July 1993.

Tree 4-10 m tall, trunk c. $12 \mathrm{~cm}$ diam.; young twigs rather densely covered with appressed hairs, soon glabrous. Leaves: petiole 2-4 mm long, 1-2 mm diam.; lamina narrowly ovate to narrowly elliptic and slightly falcate, $13-20$ by $4-6 \mathrm{~cm}$ (leaf index $2.8-3.3$ ), chartaceous, sparsely or not verrucose above, shiny above, greyish green on both sides, glabrous above, but primary vein densely covered with appressed to erect hairs (primary vein may look verrucose by remaining hair bases), sparsely to rather densely covered with appressed hairs below, base obtuse, apex acuminate (acumen 10-15 mm long), secondary veins distinct, 6-10 on either side of primary vein, strongly prominent above, angles with primary vein $60-65^{\circ}$, loop-forming at right to obtuse angles, smallest distance between loops and margin $3-5 \mathrm{~mm}$. Flowers solitary or in pairs; pedicels 3-5 $\mathrm{mm}$ long, c. $1 \mathrm{~mm}$ diam., fruiting pedicels to $7 \mathrm{~mm}$ long, to $3 \mathrm{~mm}$ diam., densely covered with appressed, dark brown hairs; sepals free, deltate, c. 6 by $6 \mathrm{~mm}$, appressed, outer side densely covered with appressed, dark brown hairs; petals cream in vivo, subequal, broadly ovate-triangular, $8-14$ by $8-11 \mathrm{~mm}$, outer side densely covered with appressed, dark brown hairs; stamens 2-2.5 mm long, connective shield papillate. Monocarps < 10, purple-black in vivo, black in sicco, narrowly ellipsoid, $10-14$ by $4-8 \mathrm{~mm}$, sparsely covered with appressed hairs, apex rounded or apiculate, stipes $1-3$ by $1 \mathrm{~mm}$, sparsely covered with appressed hairs. Seeds ellipsoid, c. 10 by $6 \mathrm{~mm}$, pale brown, slightly pitted.

Distribution - Costa Rica (Puntarenas, Osa Peninsula).

Habitat \& Ecology - Forest. At an elevation of $900 \mathrm{~m}$.

Phenology - Flowering: July, December; fruiting: July.

Note - This species resembles at first sight G. pudica N. Zamora \& Maas, but its parts are generally smaller in size (Table 2). Both species occur in the Osa area and are probably closely related.

Etymology - This species is named after Reinaldo Aguilar, an independent botanical field researcher in the Osa Peninsula (Costa Rica), who made many important general collections of Annonaceae.

Paratypes:

Costa Rica. Puntarenas: Aguilar et al. 4810 (INB), Canton Osa, Serranías de Golfito, Piedras Blancas, $100 \mathrm{~m}$. 


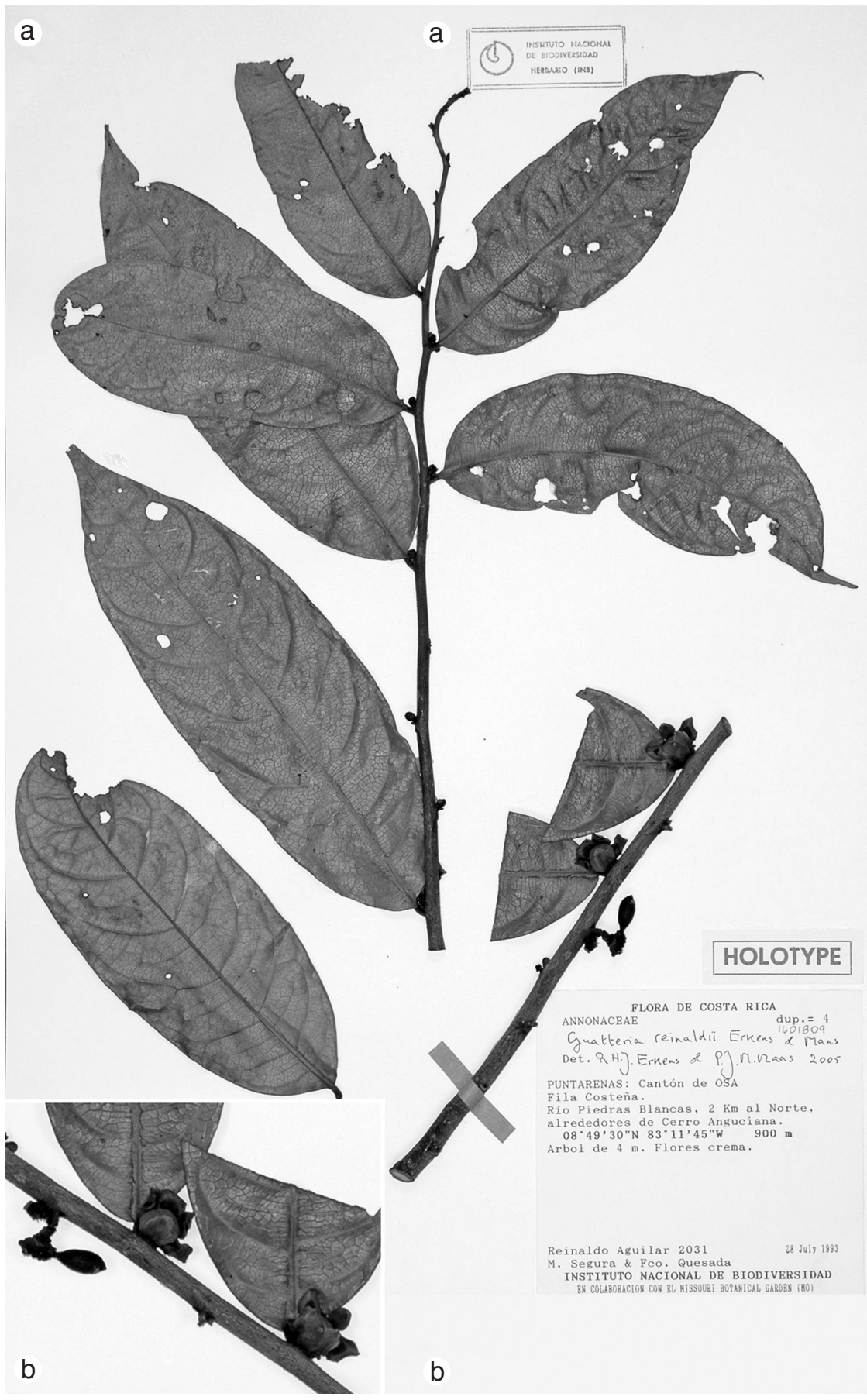

Fig. 4. Guatteria reinaldii Erkens \& Maas. a. Flowering and fruiting twig; b. close-up of fruit and flowers (all: Aguilar et al. 2031). 

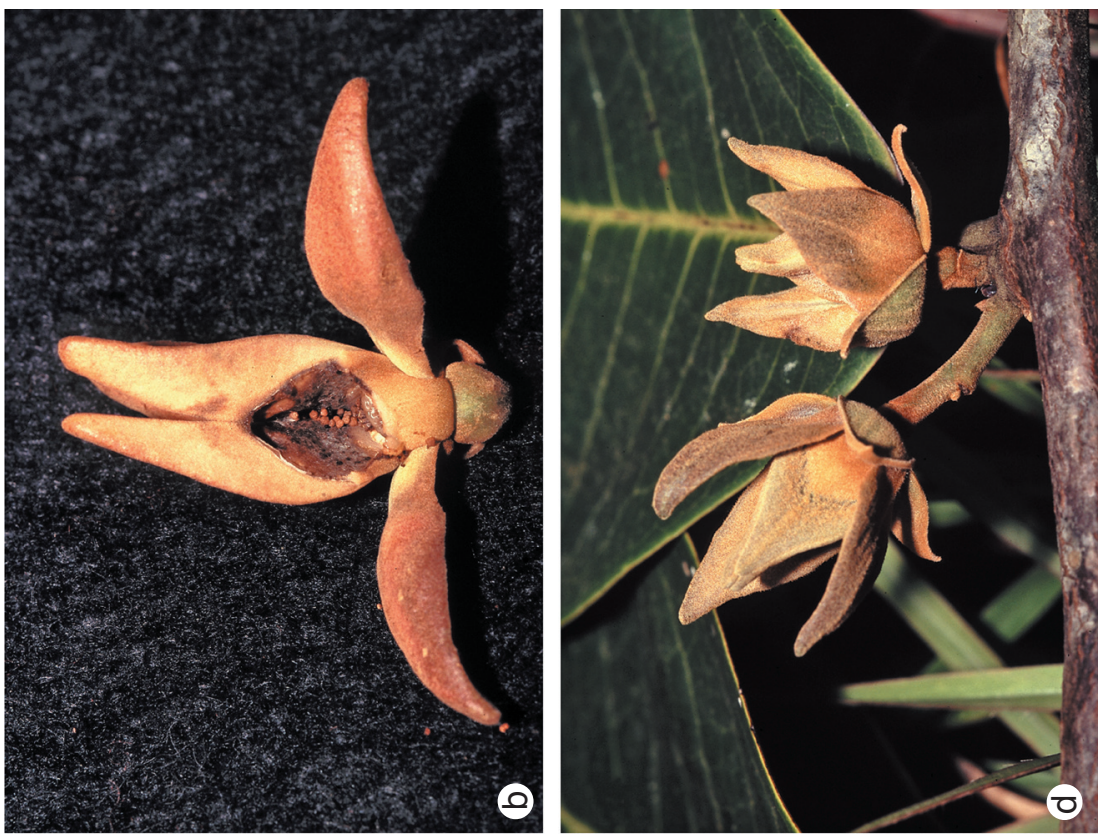

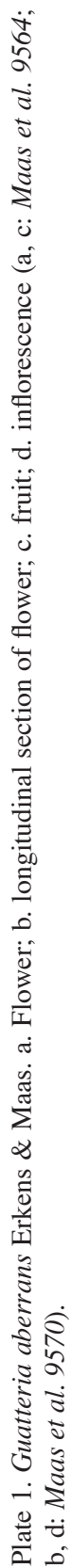
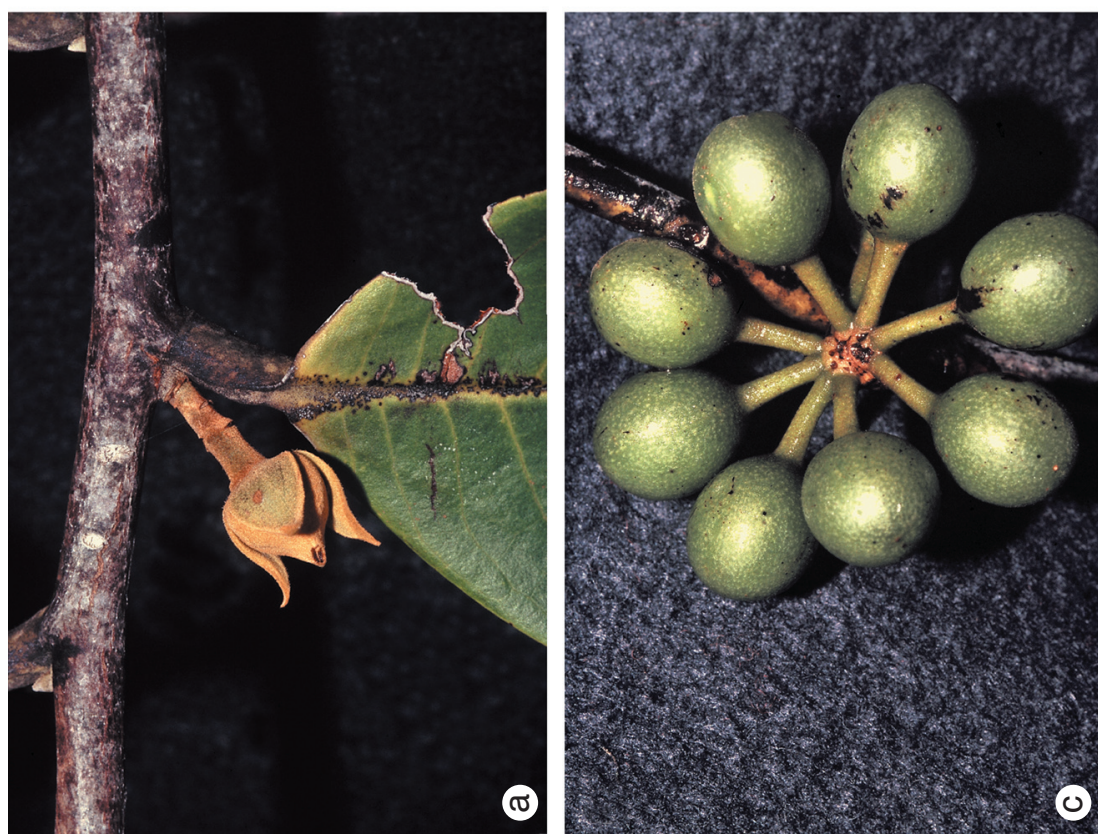

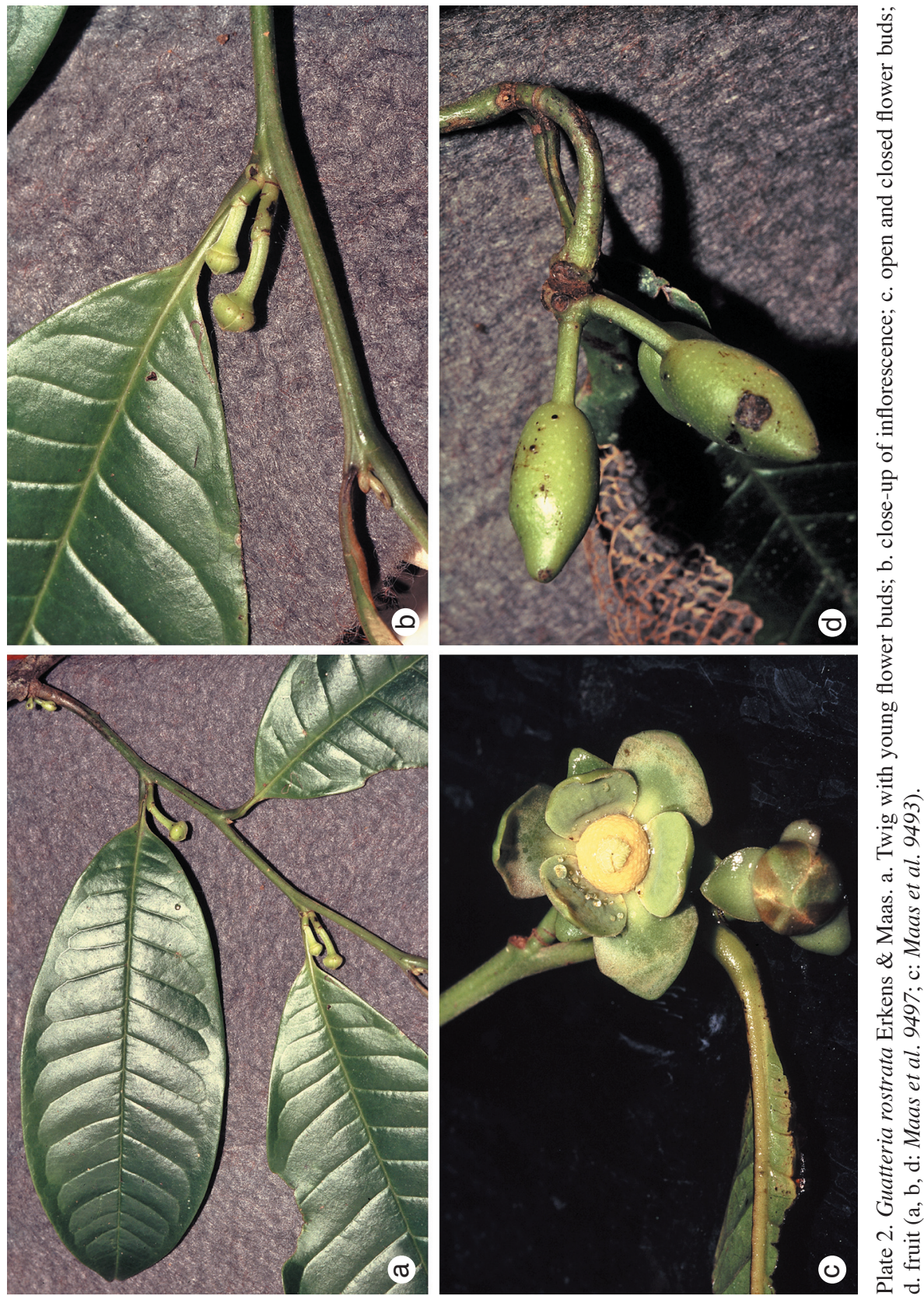

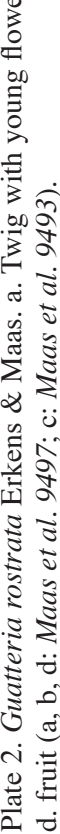


Table 2. Morphological differences between G. reinaldii Erkens \& Maas (Costa Rica) and G. pudica N. Zamora \& Maas (Costa Rica).

\begin{tabular}{lll}
\hline & G. reinaldii & G. pudica \\
\hline $\begin{array}{l}\text { Indument of young } \\
\text { twigs }\end{array}$ & $\begin{array}{l}\text { densely covered with appressed } \\
\text { hairs }\end{array}$ & densely covered with erect hairs \\
Petiole & $2-4$ by $1-2 \mathrm{~mm}$ & $5-8$ by $3 \mathrm{~mm}$ \\
Leaf base & obtuse & acute \\
Lamina & narrowly elliptic, slightly falcate; & narrowly oblong, rarely narrowly elliptic, \\
& $15-32$ by $4-9.5 \mathrm{~cm}$ & symmetrical; 10-20 by $2.5-4 \mathrm{~cm}$ \\
Secondary veins & $6-10$ & $10-20$ \\
Lower side of leaf & sparsely to rather densely covered & densely covered with erect hairs \\
& with appressed hairs & \\
Pedicel length & $3-7 \mathrm{~mm}$ & $10-17 \mathrm{~mm}$ \\
Stipe length & $1-3 \mathrm{~mm}$ & $5-10 \mathrm{~mm}$ \\
Monocarps & $<10$, narrowly ellipsoid, & $30-40$, ellipsoid, 8-11 by 4-6 mm \\
& $10-14$ by $4-8$ mm & \\
\hline
\end{tabular}

\section{Guatteria rostrata Erkens \& Maas, spec. nov. - Fig. 5; Plate 2; Map 1}

Guatteria amplifoliae proxima, sed monocarpiis rostratis distincta. - Typus: Aguilar et al. 3654 (holo U; iso CR, INB), Costa Rica, Puntarenas, Canton Osa, Reserva Forestal Golfo Dulce, near Rancho Quemado, 200-350 m, 1 November 1994.

Tree 7-20 m tall, trunk 20-60 cm diam., black or grey; young twigs densely covered with appressed hairs, soon glabrous. Leaves: petiole 15-20 mm long, 2-3 mm diam.; lamina elliptic to obovate or narrowly so, $18-28$ by $7-11 \mathrm{~cm}$ (leaf index 2.4-2.6), chartaceous, not verrucose, dull, greyish brown above, brown below, glabrous above, rather densely covered with appressed hairs below, base attenuate into a narrowly winged petiole, apex acuminate (acumen 10-20 mm long), secondary veins distinct, 16-19 on either side of primary vein, impressed above in vivo, raised above in sicco, angles with primary vein $60-70^{\circ}$, loop-forming at right to obtuse angles, smallest distance between loops and margin 3-6 mm. Flowers solitary or in pairs; pedicels $15-35 \mathrm{~mm}$ long, c. $1 \mathrm{~mm}$ diam., fruiting pedicels to $2 \mathrm{~mm}$ diam., densely covered with appressed hairs, finally subglabrous; flower buds very broadly ovoid; sepals free, triangular, 7-12 by 5-10 mm, patent, outer side rather densely covered with appressed hairs; petals green to yellowish green in vivo, unequal, outer ones ovate, $14-22$ by $10-15 \mathrm{~mm}$, inner ones oblong-elliptic to ovate, $10-15$ by $5-9 \mathrm{~mm}$, outer side densely covered with appressed hairs; stamens c. $2 \mathrm{~mm}$ long, connective shield densely papillate. Monocarps 5-15, green, maturing red to purple-black in vivo, black in sicco, narrowly ellipsoid, 15-18 by $6-7 \mathrm{~mm}$, sparsely covered with erect hairs, soon glabrous, apex rostrate (beak $1-2$ by $1-2 \mathrm{~mm}$ ), stipes $7-10$ by $1 \mathrm{~mm}$, sparsely covered with appressed hairs, soon glabrous. Seeds ellipsoid, apex slightly pointed, c. 15 by $7 \mathrm{~mm}$, pale brown, slightly tuberculate.

Distribution - Costa Rica (Puntarenas, Osa District).

Habitat \& Ecology - Forest. At elevations from sea level up to $350 \mathrm{~m}$.

Phenology - Flowering: May, July; fruiting: February, May, June, November. 


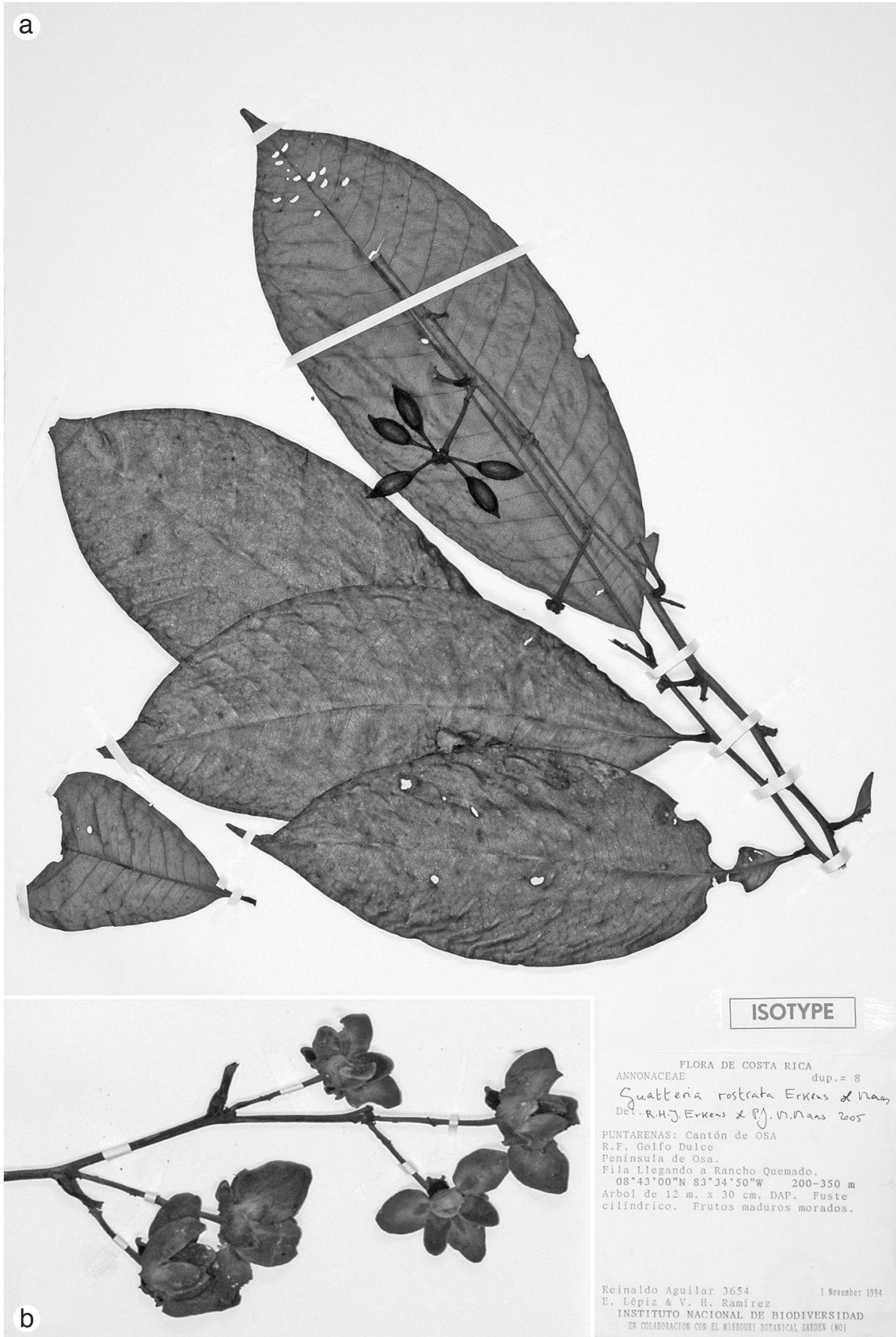

Fig. 5. Guatteria rostrata Erkens \& Maas. a. Fruiting twig; b. (inset) flowering twig (a: Aguilar et al. 3654; b: Aguilar 4611). 


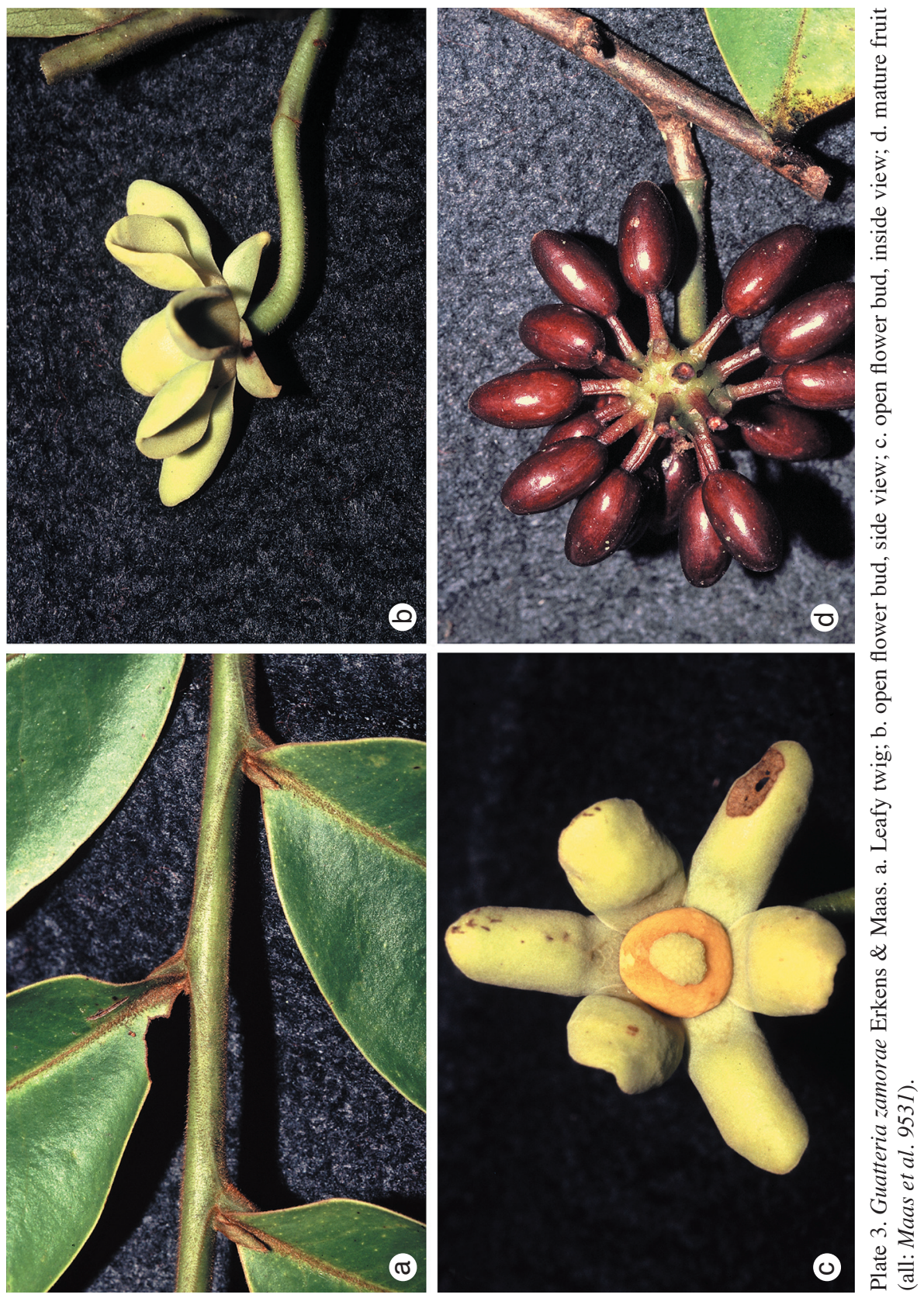



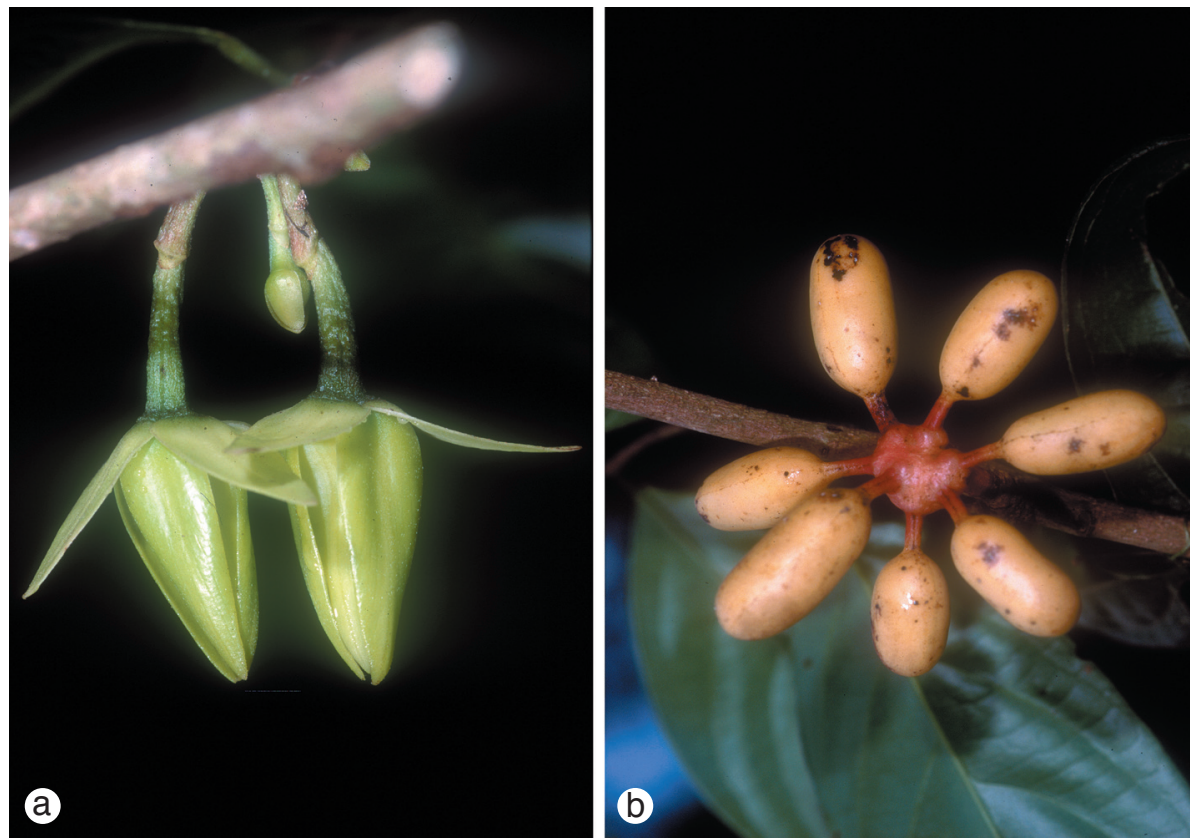

Plate 4. Desmopsis verrucipes Chatrou, G.E. Schatz \& N. Zamora. a. Immature flowers; b. immature fruit (a: Chatrou et al. 102; b: Chatrou et al. 115).

Note - In the field G. rostrata is easily recognised by its black or grey trunk, sometimes with narrow buttresses reaching up to $8 \mathrm{~m}$ (Hammel 16960). In the field this species superficially resembles G. amplifolia Triana \& Planch., somewhat because of its large leaves. In $G$. rostrata, however, the petiole is generally somewhat longer ( $15-20$ by $2-3 \mathrm{~mm}$ vs $4-10$ by $4-6 \mathrm{~mm}$ ). Moreover, the monocarps of $G$. rostrata are $5-15$ in number, $15-18$ by $6-7 \mathrm{~mm}$ and rostrate, while $G$. amplifolia has more monocarps (20-40), which are shorter ( $8-10$ by $5-6 \mathrm{~mm})$, and ellipsoid to pyriform, lacking the rostrate apex.

Etymology - This species is named 'rostrata' after its beaked (= rostrate) monocarps.

Paratypes:

Costa Rica. Puntarenas: Hammel et al. 16960 (CR, INB), Canton Osa, Reserva Forestal Golfo Dulce, near Rancho Quemado, 200 m; Aguilar et al. 4611 (CR, INB, U), Canton Osa, Reserva Forestal Golfo Dulce, Bahia Chal, 150 m; Chatrou et al. 118 (CR, INB, U), idem, 175 m; Maas, Erkens, Maas-van de Kamer, Rodríguez \& Alfaro 9493 (CR, INB, K, NY, U), Canton Osa, Distr. Rincón, 2 km before Banejas, 75 m; Maas, Erkens, Maas-van de Kamer, Rodríguez \& Alfaro 9497 (CR, INB, U), Canton Osa, Distr. Puerto Jiménez, Guadeloupe de La Palma, 100 m.

\section{Guatteria zamorae Erkens \& Maas, spec. nov. - Fig. 6; Plate 3; Map 1}

Guatteria foliis in sicco ochraceis et verrucosis, monocarpiis apiculatis distincta. Typus: Maas, Erkens, Maas-van de Kamer \& Zamora 9531 (holo U; iso INB, K, MO, NY, PMA, SCZ), Panama, Bocas del Toro, Canaza, road from Chiriquí Grande to David, 100 m, 29 May 2004. 


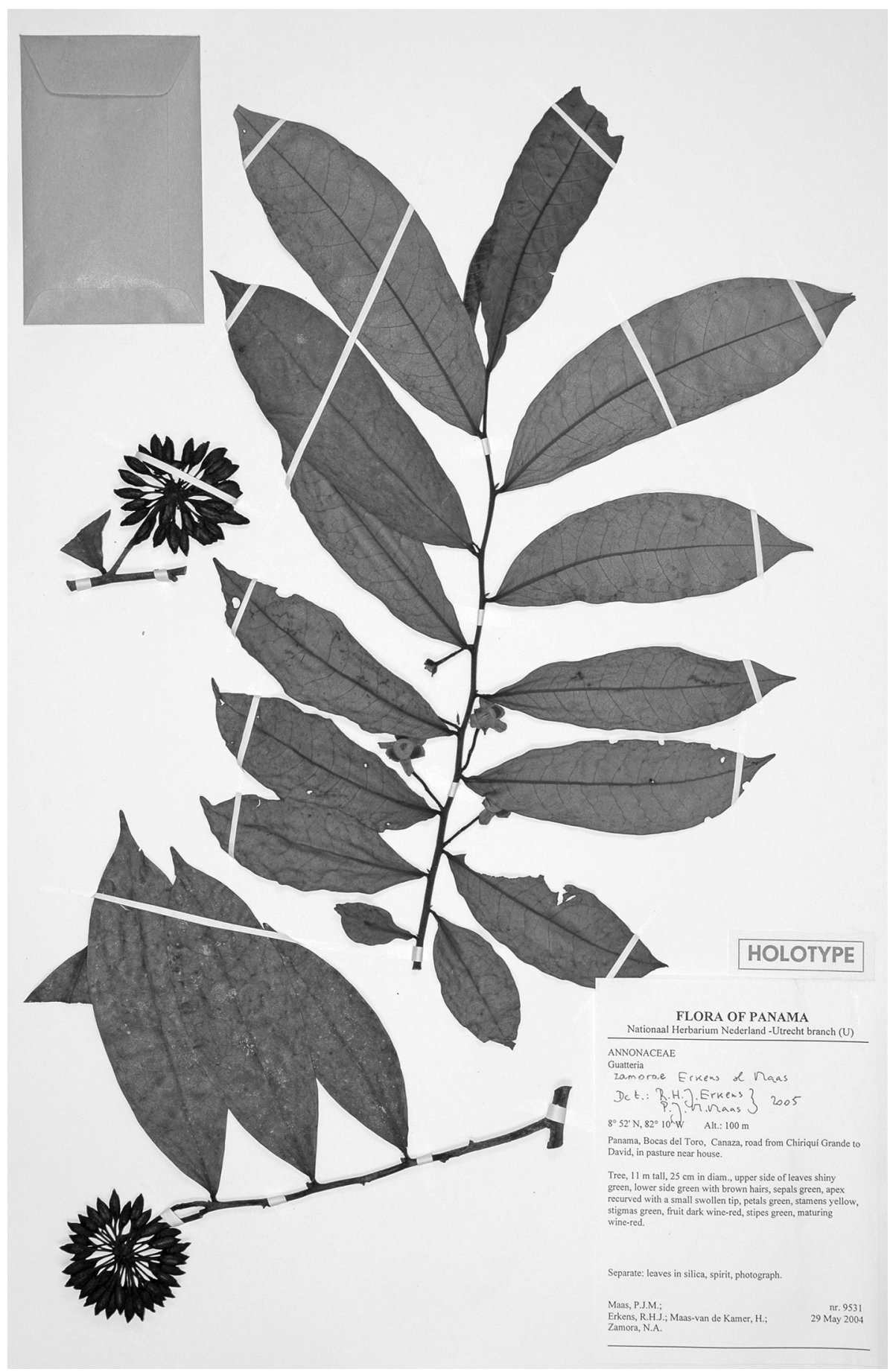

Fig. 6. Guatteria zamorae Erkens \& Maas. Flowering and fruiting twigs (Maas et al. 9531). 
Tree 11-15 m tall, trunk 25-30 cm diam.; young twigs densely covered with erect, brown hairs, finally glabrous. Leaves: petiole 3-9 $\mathrm{mm}$ long, 1-2 $\mathrm{mm}$ diam.; lamina narrowly obovate to narrowly elliptic, $10-17$ by $3-5 \mathrm{~cm}$, chartaceous, rather densely to densely verrucose above, greenish brown above, yellowish brown below, glabrous above except for the densely hairy primary vein and secondary veins, densely covered with erect, brown hairs below, base acute, apex acuminate (acumen 5-10 mm long), secondary veins distinct, $10-15$ on either side of primary vein, prominent above, angles with primary vein $55-65^{\circ}$, loop-forming at right to obtuse angles, smallest distance between loops and margin 2-3 mm. Flowers solitary; pedicels $25-30 \mathrm{~mm}$ long, 1-1.5 $\mathrm{mm}$ diam., fruiting pedicels up to $35 \mathrm{~mm}$ long, up to $2 \mathrm{~mm}$ diam., densely covered with erect hairs; flower buds depressed ovoid, apiculate; sepals free, very broadly ovate-triangular, $4\{-8\}$ by $4-5\{-8\} \mathrm{mm}$, patent, extreme apex rolled inwards and thickened, outer side rather densely to densely covered with appressed and erect hairs; petals green to greyish green in vivo, subequal, ovate to ovate-oblong, $10-12\{-18\}$ by $5-7\{-10\} \mathrm{mm}$, outer side densely covered with appressed and erect hairs; stamens yellow, connective shield densely papillate. Monocarps 30-50, green, maturing dark wine-red in vivo, black in sicco, ellipsoid, $9-12\{-15\}$ by $4-5\{-7\} \mathrm{mm}$, glabrous except for some scattered hairs near the apex, apex apiculate (apicle 1-2 mm long) in dry material, rounded in fresh material, stipes green, maturing dark wine-red in vivo, $6-10$ by $1\{-2\} \mathrm{mm}$. Seeds narrowly ellipsoid, $8-10$ by $3-4 \mathrm{~mm}$, tuberculate.

Distribution - Panama (Coclé).

Habitat \& Ecology - Forest and pasture. At elevations of 100 and $750 \mathrm{~m}$.

Phenology - Flowering and fruiting: May.

Notes - Guatteria zamorae can easily be distinguished from the other Central American species of Guatteria by the yellowish brown leaf colour after drying, its verrucose leaves, and apiculate monocarps. Preliminary unpublished phylogenetic analyses suggest that this species belongs to a group comprising three Central American species, namely G. talamancana N. Zamora \& Maas, G. oliviformis Donn.Sm., and G. allenii R.E. Fr. Two bracts were seen around the flower buds, both triangular, one $4\{-6\}$ by $3\{-4\} \mathrm{mm}$ and the other $5\{-8\}$ by $4\{-5\} \mathrm{mm}$. This is interesting because $G$. talamancana is known for its very large bracts $(25-30 \mathrm{~mm})$ on the pedicel. The latter, however, has a thick brown indument all over the leaf, while G. zamorae only has densely hairy primary and secondary veins.

Measurements taken from spirit material of stipes gave a smaller length than that from dried material, namely 3-5 mm long.

Etymology - This species is named after Nelson Zamora, the curator of the Herbarium of INBio (Instituto Nacional de Biodiversidad) in Costa Rica, without whom this field trip would have been impossible. The authors greatly acknowledge his help in providing fieldwork gear, a car, and a tremendous good eye for spotting Annonaceae species in the field. He himself went through great trouble in collecting this new species with the aid of a crossbow.

Paratypes:

PANAMA. Coclé: Maas, Erkens, Maas-van de Kamer, Zamora \& Navas 9542 (INB, PMA, SCZ, U), Parque Nacional General Omar Torijos Herrera, El Copé, Sendero Rana Dorada, 750 m. 


\section{DESMOPSIS}

Desmopsis verrucipes Chatrou, G.E. Schatz \& N. Zamora, spec. nov. - Plate 4; Map 1

Haec species inflorescentia ut apparet thyrsoidea, pedicellis verrucosis en sepalis magnis persistentibus distincta est. - Typus: Chatrou, Oosterhof \& Aguilar 102 (holo U; iso CR, INB, MO), Costa Rica, Puntarenas, Cantón Osa, $5 \mathrm{~km}$ from Bahia Chal, near mouth of Río Rincón, 50 m, 29 November 1998.

Treelet to $8 \mathrm{~m}$ tall, trunk $2-4 \mathrm{~cm}$ diam.; young twigs, below sparsely covered with appressed, yellowish brown hairs $0.1-0.2(-0.4) \mathrm{mm}$ long. Leaves: petiole $5-13 \mathrm{~mm}$ long, (1-)2 mm diam., canaliculate, drying dark; lamina narrowly elliptic to elliptic, often slightly falcate and slightly asymmetric, $13-32$ by $4.5-12.5 \mathrm{~cm}$, chartaceous, densely verruculose on both sides, olive green on both sides, petioles, both sides of primary vein, and margin of leaf blade below sparsely covered with appressed, yellowish brown hairs $0.1-0.2(-0.4) \mathrm{mm}$ long, base narrowly to broadly cuneate, apex acuminate (acumen 5-20 mm long), primary vein impressed above, secondary veins 7-14 on either side of primary vein, raised above, irregularly spaced, curving upwards, angles with primary vein $(35-) 55-60(-75)^{\circ}$, only weakly loop-forming at acute to right angles, smallest distance between loops and margin 2-6 $\mathrm{mm}$. Inflorescences essentially terminal, but mostly pseudolateral due to overtopping by the axillary shoot, and often appearing along internodes on slightly older, leafless branches, thyrsoids with mostly two rhipidia, central axis 3-6 $\mathrm{mm}$ long, $1-3 \mathrm{~mm}$ diam., axial internodes $1-3$ $\mathrm{mm}$ long, rhipidia up to 3 -flowered (including flower buds); peduncles, pedicels, and bracts sparsely to rather densely covered with brown, appressed hairs $0.1-0.2 \mathrm{~mm}$, articulation of pedicel clearly visible as a ring of hairs $1-3 \mathrm{~mm}$ above lower bract, subtending the pedicel, uppermost bract at $1 / 3$ from base of pedicel; bracts depressed ovate, semi-amplectent, c. 2 by c. $4 \mathrm{~mm}$, pedicels $8-19$ by $1-3 \mathrm{~mm}$ (to $7 \mathrm{~mm}$ in fruiting stage), vertically striate and verrucose, even more so in fruiting stage; sepals free, maturing red in vivo, foliaceous with visible venation, persistent, often still present in fruit, ovate to triangular, $9-20$ by $5-10 \mathrm{~mm}$ wide, apex acute, ciliate, verruculose on both sides, outer side rather densely covered with brown, appressed hairs c. $0.2 \mathrm{~mm}$ long; petals maturing white in vivo, subequal, narrowly triangular, $15-30$ by $5-8 \mathrm{~mm}$, apex acute, inner petals slightly narrower than outer ones, ciliate, outer side rather densely covered with brown, appressed hairs c. $0.2 \mathrm{~mm}$ long, inner side glabrous except for apex; stamens $80-150,1.5-2 \mathrm{~mm}$ long, filament $0.3 \mathrm{~mm}$ long, anther connective shield discoid, $0.1 \mathrm{~mm}$ thick, glabrous; carpels $15-25$, ovary prismatic, $1.6-2 \mathrm{~mm}$ long, sparsely covered with short, appressed hairs to glabrous (except for extreme base), stigma globose, c. $0.3 \mathrm{~mm}$ diam., totally covered with white hairs $0.1 \mathrm{~mm}$, ovules 4-6 in a single row. Monocarps 7-20, maturing yellow in vivo, black in sicco, ellipsoid, $12-29$ by $8-14 \mathrm{~mm}$, glabrous, apex rounded, stipes maturing dark red in vivo, $5-12$ by $1-2 \mathrm{~mm}$, subglabrous to sparsely covered with brown, appressed hairs c. $0.2 \mathrm{~mm}$ long. Seeds flattened discoid, $8-10$ by $2-3 \mathrm{~mm}$, surface smooth, light reddish brown, the raphe a shallow equatorial furrow.

Distribution - South-western Costa Rica, known only from the Golfo Dulce area, including the Osa Peninsula.

Habitat \& Ecology - Tropical wet forests. At elevations of 0-250 m. 
Phenology - Flowering: August through November; fruiting: October through March.

Notes - The verrucose pedicel, the large, persistent sepals, and the thyrsoid inflorescences that usually are borne on older, leafless branches, distinguish $D$. verrucipes.

The inflorescences of $D$. verrucipes are described as a thyrsoid in the sense of Weberling \& Hoppe (1996), viz. a ramification system with cymosely branched partial inflorescences on a multinodate main axis, which ends in a terminal flower. In this new species, no more than two 'partial inflorescences', rhipidia, have been observed per inflorescence. A peculiar feature of the rhipidia is the fact that successive flowers are not arranged in one plane, i.e. the flowers do not alternate at angles of $180^{\circ}$, but at a much smaller angle. A similar deviation from the usual rhipidiate inflorescence in Annonaceae was reported for Fusaea (Chatrou \& He, 1999).

This publication validates the name $D$. verrucipes, already mentioned by Zamora et al. (2000); Schatz (1987) listed this species provisionally under the name D. walkeri.

Etymology - The name of this new species refers to the verrucose pedicel, noticeable in flowering, but especially in fruiting stage.

Paratypes:

Costa Rica. Puntarenas: Aguilar 5274 (INB, U), Cantón Golfito, Laguna Pejeperrito, 0 m; Chatrou, Oosterhof \& Aguilar 115 (CR, INB, K, MO, U), Cantón Golfito, Dos Brazos del Tigre, 250 m; Fonseca 23 (CR, MO), Cantón Osa, Parque Nacional Corcovado, 10 m; Kernan 282 (MO, U), Parque Nacional Corcovado, 0-150 m; Kernan 801 (MO), without locality information, 0 m; Knapp \& Mallet 2202 (MO), Parque Nacional Corcovado, ridges above Río Claro, 0-100 m; Maas, Maas-van de Kamer, Hammel \& Chavarría 7839 (INB, U), Cantón Osa, 2 km from Chacarita, S of Palmar Norte; Neill 5049A (MO), without locality information, 200 m; Salas 182 (CR, DUKE, F, GH, MO, WIS), Golfito; Thomsen 197 (CR, K, U, USJ), Río Riyito, 50 m; Todzia \& Gilbert 1709 (TEX), near edge of Río Sirena; Walker 193 (CR, DUKE, F, GH, MO, WIS), forest above United Fruit Company's headquarters, $2 \mathrm{~km} \mathrm{~N}$ of Golfito, $10-20 \mathrm{~m}$.

\section{PSEUDOMALMEA}

\section{Pseudomalmea darienensis Chatrou, spec. nov. - Fig. 7; Map 1}

A speciebus ceteris in genere Pseudomalmea foliis magnis, pedicello bractea supra articulationem instructo et stipite brevi differt. - Typus: McPherson, Hensold, Palacios, Herrera \& Polanco 15345 (holo U; iso MO), Panama, Darién, S of Garachine on W flank of Serranía Sapo, above place called Casa Vieja, 50-150 m, 21 May 1991.

Tree 14-25 m tall, young twigs glabrous. Leaves: petiole 4-5 mm long, c. $1.5 \mathrm{~mm}$ diam.; lamina narrowly elliptic to elliptic, $12-19$ by $4-8 \mathrm{~cm}$, chartaceous, on both sides with uneven light to dark brown patches, petioles, lower side of primary vein, basal part of leaf blade and primary vein below sparsely to rather densely covered with brownish, appressed hairs $0.2-0.6(-0.8) \mathrm{mm}$ long, base (shortly) attenuate, apex gradually acuminate (acumen 5-14 mm long), secondary veins 7-10 per side, irregularly spaced, angles with primary vein $45-70^{\circ}$, indistinctly loop-forming at acute-right angles, distance between loops and leaf margin 3-7 mm, intersecondaries present, tertiary venation reticulate with few percurrents. Infructescences on older, leafless branches; pedicels 9-25 by c. $3 \mathrm{~mm}$ basally to c. $4 \mathrm{~mm}$ apically, bract above articulation semi-amplectent, c. $1 \mathrm{~mm}$ by c. $2.5 \mathrm{~mm}$; pedicels and outer side of bracts rather densely covered with brown, appressed hairs 0.2-0.4(-0.6) mm long. Flowers unknown. Monocarps 10-15, red 


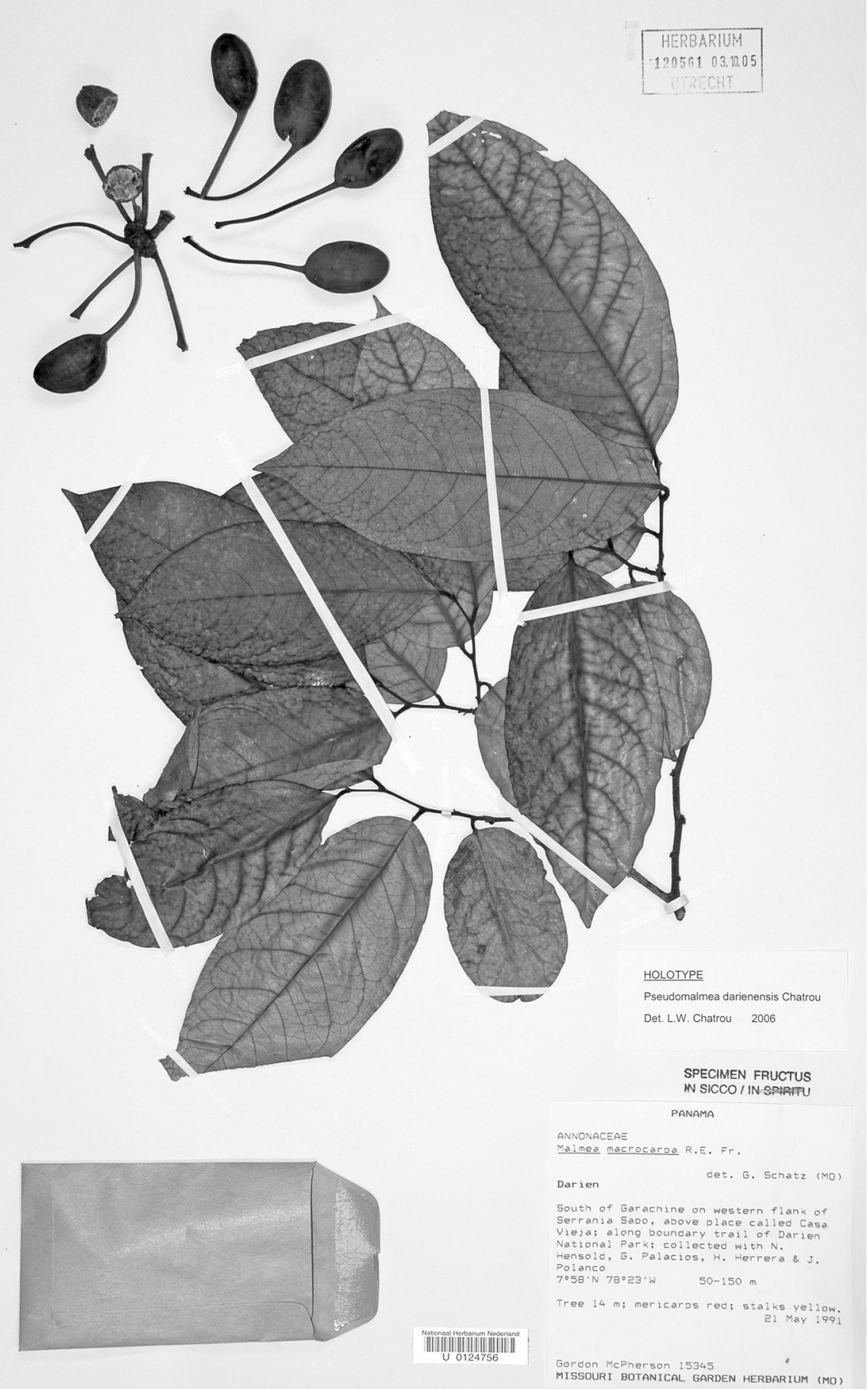

Fig. 7. Pseudomalmea darienensis Chatrou. Leafy twig and fruit (McPherson 15345). 
at maturity in vivo, (reddish) brown in sicco, ellipsoid, $18-32$ by $11-19 \mathrm{~mm}$, sparsely covered with yellowish brown, appressed to erect hairs $0.2-0.6 \mathrm{~mm}$ long, verrucose to rugose, stipes $22-32(-44)$ by $1-2 \mathrm{~mm}$, sparsely covered with yellowish brown, appressed to erect hairs $0.2-0.6 \mathrm{~mm}$ long, fruiting receptacle transversely ellipsoid, 11-15 mm diam., 6-8 mm high, densely hairy. Seeds ellipsoid, 16-30 by $9-17 \mathrm{~mm}$, reddish brown, shallowly transversely striate, raphe slightly raised.

Distribution - Panama, only known from two collections made in the province of Darién.

Habitat \& Ecology - Tropical wet forest. At elevations of up to $150 \mathrm{~m}$.

Phenology - Fruiting: January through May.

Note - Despite the availability of two fruiting specimens only, the material clearly represents a new species, and $P$. darienensis is published to further document the rich flora of Panama, and Darién in particular.

Etymology - The name of this new species refers to the Panamanian state of Darién, in which both collections have been made.

Paratype:

Panama. Darién: Garwood, Gibby, Hampshire \& Humphries 265 (BM, MO), Ensenada del Guayabo, 18 km SE of Jaqué, $100 \mathrm{~m}$.

\section{KEY TO THE SPECIES OF PSEUDOMALMEA}

Pseudomalmea darienensis is the fourth species within the genus, and the first one to be described for Central America. Given the recent doubling of the size of the genus due to the publication of $P$. dariensisis here, and of $P$. wingfieldii (Chatrou \& Pirie, 2005), it is appropriate to present a key to the species of Pseudomalmea here.

1a. Primary vein on lower side glabrous or uniformly covered with appressed hairs 2

b. Primary vein on lower side covered with patches of erect hairs . . . P. boyacana

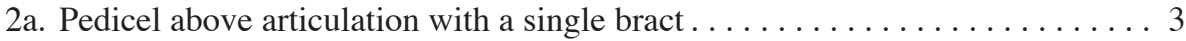

b. Pedicel above articulation without a bract. ............ . wingfieldii

3a. Lower side of leaves subglabrous, fruiting receptacle glabrous, stipes and monocarps

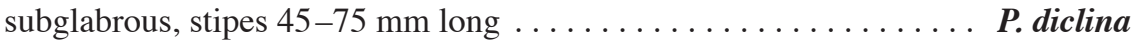

b. Lower side of leaves sparsely to rather densely hairy, fruiting receptacle densely hairy, stipes and monocarps sparsely hairy, stipes $22-32(-44) \mathrm{mm}$ long . . . . .

P. darienensis

\section{ACKNOWLEDGEMENTS}

We thank the Miquel Foundation, the Netherlands Organisation for Scientific Research, and Shell Netherlands BV (by means of a Personal Development Award) for funding. We are also indebted to Nelson Zamora and Reinaldo Aguilar for assistance during our stay at the Instituto Nacional de Biodiversidad (INBio, Costa Rica) and during fieldwork, and the INBio for providing workspace and equipment. We thank Mirreya Correya for her hospitality at the herbarium of the University of Panama, and Carmen Galdames for her assistance there. Furthermore, the field guides who have accompanied us in Costa Rica and Panama, and without whom our fieldwork would not have been so successful: José González, Francisco Morales, Barry Hammel, Alexander Rodriguez, Evelio Alfaro, Rafael Aizprúa, Alicia Ibañez, Pedro Caballero, Santiago Navas, and Rolando Pérez. Lastly, Leon Commandeur for photographing herbarium specimens, and Lubbert Westra for translating the diagnoses. 


\section{REFERENCES}

Chatrou, L.W. \& P. He. 1999. Studies in Annonaceae XXXIII. A revision of Fusaea (Baill.) Saff. Brittonia 52: 181-203.

Chatrou, L.W. \& M.D. Pirie. 2005. Three new rarely collected or endangered species of Annonaceae from Venezuela. Blumea 50: 33-40.

Chatrou, L.W., H. Rainer \& P.J.M. Maas. 2004. Annonaceae. In: N. Smith, S.A. Mori, A. Henderson, D.W. Stevenson \& S. V. Heald (eds.), Flowering plants of the Neotropics: 18-20. Princeton University Press, New Jersey.

Erkens, R.H.J., L.W. Chatrou, J.W. Maas \& V. Savolainen. In prep. A major radiation of rainforest trees from Central into South America. Molec. Phylogenet. Evol.

Fries, R.E. 1939. Revision der Arten einiger Annonaceen-Gattungen V. Acta Horti Berg. 12: 289_ 577.

Ruiz Lopez, H. \& J.A. Pavón. 1794. Florae peruvianae, et chilensis prodromus. Imprenta de Sancha, Madrid.

Scharf, U., P.J.M. Maas \& W. Morawetz. 2005. Five new species of Guatteria (Annonaceae) from the Pakaraima Mountains, Guyana. Blumea 50: 563-573.

Schatz, G.E. 1987. Systematic and ecological studies of Central American Annonaceae. PhD thesis, University of Wisconsin, Madison.

Weberling, F. \& J.R. Hoppe. 1996. Comparative morphological evaluation of inflorescence characters in Annonaceae. In: W. Morawetz \& H. Winkler (eds.), Reproductive morphology in Annonaceae. Biosystematics and Ecology Series 10: 29-53. Austrian Academy of Sciences, Vienna.

Zamora V., N., Q. Jiménez M. \& L.J. Poveda A. 2000. Árboles de Costa Rica, Vol. II. Instituto Nacional de Biodiversidad, Santo Domingo de Heredia, Costa Rica. 